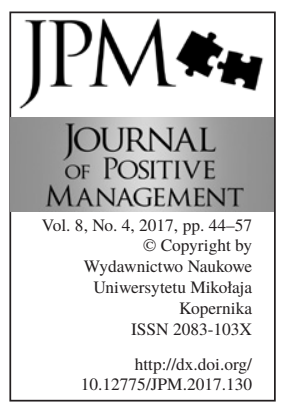

\title{
THE ROLE OF OCCUPATIONAL AND DEMOGRAPHIC FACTORS IN RELATION TO WORK ENGAGEMENT IN POLISH SAMPLE OF EMPLOYEES - INITIAL STUDY
}

\author{
Magdalena Jaworek \\ Institute of Economics, Finance and Management, Jagiellonian Univesity \\ e-mail: magdalena.jaworek@uj.edu.pl
}

\begin{abstract}
Purpose: The aim of the present study is to analyze the differences in work engagement in terms of occupational groups (teachers, nurses, physicians, policemen, telesales operators, blue collar workers, employing in accounting/finance, sales representatives, welfare services/rehabilitation, office workers in public sector, and bank and IT employees), job position (managerial and nonmanagerial), age, and gender in Polish sample of employees.

Methodology: A cross-sectional questionnaire survey was conducted among 3186 employees representing different occupational groups. The measure was the Utrecht Work Engagement Scale (UWES-9) by Schaufeli and Bakker (2003). To examine differences in work engagement in terms of occupational group and age, one-way ANOVA and post-hoc tests (Tukey's HSD) were conducted. Differences in work engagement concerning job position and gender were performed using independent samples $t$ tests.

Findings: The findings indicated that employees differ in work engagement depending on studied factors. In terms of occupational group, the most engaged are sales representatives, welfare services/ rehabilitation, and teachers, and least engaged - telesales operators and blue collar workers. Older employees $(+50)$ appeared to be more engaged than youngers, as well managers in comparison to non-managers. While women reported higher level of absorption and dedication than men, but no gender differences were observed in regard to vigor.

Implications: Results show that occupational factors, as profession and job position, as well demographic ones should not be ignored in relation to work engagement. Managers, in order to increase engagement among their subordinates should pay special attention to some groups of employees in terms of age, gender, and the occupation.

Originality/value: The current study extends previous research by examining occupational and demographic differences in the level of work engagement. To the best of author's knowledge this is the first examination of this type conducted in such large sample among Polish employees.
\end{abstract}

Keywords: work engagement, occupational groups differences, gender differences, age differences, job position differences, Polish employees

Paper Type: Research paper 


\section{Introduction}

One of the first definition of engagement in job context was formulated by Kahn (1990) as harnessing of organization member's selves to their work roles; in engagement, people employ and express themselves physically, cognitively, and emotionally during role performances). Since that time, rising interest in issues related to the work engagement may be observed among both practitioners and academics, especially work and organizational psychologists. Research on work engagement fit into the positive psychology - relatively new trend in this discipline, which focused on bright side of human life, including professional sphere (see: Bakker et al., 2008).

High work engagement among employees provides advantages both to the individual and organization. As positive state of mind (see: Schaufeli et al., 2002) is associated with positive emotions, like happiness, joy, and enthusiasm (Salanova and Schaufeli, 2007), what can be translated into individual wellbeing (Shimazu et al., 2015). Engaged employees report less psychosomatic complaints (Schaufeli et al., 2008; Schaufeli and Bakker, 2004; Demerouti et. al., 2001) in comparison to their non-engaged counterparts. And finally, what is significant for organizations, people who report high level of work engagement demonstrate better job performance (Bakker et al., 2004; Gierveld and Bakker, 2005; Salanova et al., 2005; Shimazu et al., 2015; Bakker and Bal, 2010).

According to some theorists, like Maslach and Leiter (1997), work engagement is the opposite of burnout syndrome, described by a combination of emotional exhaustion, depersonalization/cynicism and reduced sense of efficacy. Thus, work engagement as reversed phenomenon, is defined by high energy, strong involvement and sense efficacy. Such understanding the work engagement implies that employees who are disengaged at their work are burn out, and vice versa. Other academics consider work engagement as much more complicated phenomenon, however negatively related to burnout. In line with Schaufeli, Salanova et al. (2002), work engagement is a work-related, positive state of fulfillment in employees, characterized by vigor, dedication, and absorption. Vigor means vitality, high energy, and mental resilience, which let individual constantly works even in the face of difficulties. Dedication is characterized by enthusiasm, inspiration, and sense of significance and this term is similar to job involvement. Absorption refers to being fully concentrated and deeply engrossed in one's work, what is close enough to the term of flow in the meaning of Csikszentmihalyi (1990). Some results of investigations show, that absorption links work engagement and workaholism (see: Jaworek and Dyląg, 2016; Schaufeli et al., 2008), which is entirely different phenomenon, regarded as negative and undesirable in terms of employee health. Overall, the concept of work engagement according to Schaufeli et al. (2002) is the most well-known among scholars and such understanding will be practiced in that study. 
THE ROLE OF OCCUPATIONAL AND DEMOGRAPHIC

Magdalena Jaworek
Most investigations on work engagement concentrates on organizational or personal determinants of this phenomenon, as well consequences like job performance or work-related wellbeing (i.e. Shimazu et al., 2015; Narainsamy and Westhuizen, 2013; Rothmann, 2008; Bakker and Bal, 2010). The aim of current study is to analyze the work engagement in terms of individual factors, but mainly related to professional sphere. One of them is occupational group. Specificity of occupation results from job tasks and duties or/and work environment adjusted to the profession (or vice versa). The few studies investigated this relations indicate, that the level of work engagement may depend on occupation (Innstrand, 2016; Schaufeli et al., 2006). Another analyzed factor in relation to the work engagement is job position: managerial and non-managerial. As people who holds power should demonstrate higher level of soft skills in comparison to their subordinates, it is predicted, that managers are more engaged at work also. These assumption is also supported by empirical investigations. For example, in studies by BabcockRoberson and Strickland (2010) found the association between work engagement, charismatic leadership, and organizational citizenship behaviors. The last studied factors in terms of work engagement are age and gender. Results of some studies indicate that older workers report higher level of work engagement (e.g. James et al., 2010, 2012; Robinson et al., 2004; Towers Perrin, 2005; Schaufeli et al., 2006), what seems to be contrary to common knowledge and assumptions. In turn, gender turned to be differentiating factor of the level of engagement at work in studies by Bakker and Schaufeli (2003) and Stayn and Grobler (2016), and to some extent by Schaufeli et al. (2006).

Determinants of work engagement are usually explained by the Job DemandsResources (JD-R) model (Demerouti et al., 2001). Job demands refer to those aspects of the job that require sustained physical and /or psychological effort (Bakker et al., 2003) and are related to certain physiological and/or psychological costs. Examples of job demands are work pressure, role overload, poor environmental conditions. Job resources help the individual to achieve work goals, stimulate personal growth and development, and buffer impact of job demands. Direct relationships between work engagement and job resources, like performance feedback, support from colleagues or supervisory coaching was also confirmed in empirical studies (e.g. Schaufeli and Bakker, 2004). It seems, that some occupations are associated with certain job resources and job demands regardless of work place. For example, the occupation of supermarket cashier characterize low task variety and high demands associated with monotony and physical constraints. Thus, in line of JD-R model it can be assumed that work engagement among representatives of that occupation is lower in comparison to, e.g. managers whose work is rich with diverse tasks.

Work engagement can be considered at level of personal resources also (see: 
theory $(1989,2006)$. According to that concept, individuals acquire and maintain resources in the form of objects, personal characteristics, conditions, and energies. Primarily, Hobfoll's theory was developed in order to explain people's behaviors in stressful circumstances - the more resources one possess, the more resilience to stress he/she is (Hobfoll, 1989). In line with the COR theory, job, through position at work, steady employment, sense of independence, satisfactory income, etc. (2006, p. 87) belongs to personal resources. Resources can be objectively valuable, like well-paid job, or subjective, when someone does what he/she likes and job meets his/her individual needs. In that case the person-job fit is important, what is the resource in itself. Thus, in line with COR concept, in occupations which provide individuals more personal resources in the meaning of the person - job fit, than others, it can predict higher level of work engagement in comparison to occupational groups associated with fewer resources.

The COR concept seems to be linked to the theory by Schneider (1987) to some extent. According to Schneider, attraction to an organization, selection by it, and attrition from it yield particular kinds of persons in an organization.... However, it concerns organizational setting, but it can be applied to the occupation or job position also. Especially, as Schneider refers to Holland's theory (see: Schneider, 1987). As fitting job - person belongs to personal resources through meeting individual needs, people usually choose such occupation which are correspond to their dispositions, values, etc. In other perspective, occupation attracts people with certain dispositions. In turn, HR managers in recruiting try to select the best candidates on given position in terms of not only professional skills but also personal dispositions. Thus, people who represent some occupational groups may represent certain dispositions, which, in turn, can be associated just with work engagement, what confirmed some investigations. It was found positive relationships between work engagement and some personality traits, like extraversion, agreeableness, conscientiousness, openness to experience (Zaidi et al., 2013), sense of coherence (Bezuidenhout and Cilliers, 2010), Type A behavior (Hallberg et al., 2007), optimism, self-efficacy, self-esteem (Xanthopoulou et al., 2007), resilience, and active coping style (see: Bakker et al., 2008).

Thus, based on theoretical assumptions and some empirical studies, it is predicted that representatives of different professions differ from each other in terms of work engagement (Hypothesis 1 ) and employees who hold managerial position are more engaged in the work than non-managers (Hypothesis 2). As regards age, in line with common knowledge it seems that younger employees should be more engaged at work then elders, because youth associates with energy, vitality (vigor), enthusiasm and motivation to live and act. But, results of studies are contradictory with this assumption (e.g. James et al., 2011; Robinson et al., 2004; Towers Perrin, 2005; Hoole and Bonnema, 2015), so it is predicted that older employees are more engaged in the work than younger ones in studied
THE ROLE OF OCCUPATIONAL AND DEMOGRAPHIC

Magdalena Jaworek 
THE ROLE OF OCCUPATIONAL AND DEMOGRAPHIC

Magdalena Jaworek sample as well (Hypothesis 3). Concerning the relationship between gender and work engagement, these few studies indicate higher level of work engagement in comparison to women (Bakker and Schaufeli, 2003; Steyn and Grobler, 2016), thus it is predicted gender differences in Polish sample also (Hypothesis 4).

\section{Research methodology}

Data were gathered between 2012 and 2016 by psychology and management students of SWPS and Jagiellonian University in Poland. Collected data were used in their MA theses.

To examine differences in work engagement in terms of occupational group and age, one-way ANOVA and post-hoc tests (Tukey's HSD) were conducted. Differences in work engagement concerning job position and gender were performed using independent samples $t$ tests. As in some cases, groups are obviously unequal (i.e. 585 to 89 in occupational groups, or 371 to 1066 in age groups) it was decided to perform random selection, fitting size of the groups to the smallest one within studied factor. In case of occupational group it was selected 100 subjects per occupation. Three occupational groups because of small size (equal or less than 80 ) were excluded. Moreover, two age groups were combined: $51-60$ and +60 , because the last one was relatively small $(n=62)$. In all cases, Levene's tests for equality of variances have been passed $(p>0.05)$.

\subsection{Method}

Work engagement was measured with short version of the Utrecht Work Engagement Scale (UWES-9), which includes three 3-items subscales: Vigor $(\mathrm{M}=3,55 ; \mathrm{SD}=1,25)$, Dedication $(\mathrm{M}=3,95 ; \mathrm{SD}=1,31)$, and Absorption $(\mathrm{M}=3,57$; $\mathrm{SD}=1,30$ ). Internal consistencies (Cronbach's alpha) for the whole scale was $\alpha=, 91$, and for subscales: $\alpha=, 82$ (vigor and dedication), and $\alpha=, 76$ (absorption). The Polish version of the UWES-9 was retrieved from www.schaufeli.com. All items were scored on a 7-point scale ranging from 0 (never) to 6 (always).

\subsection{Sample}

The sample included 3186 Polish employees consisting of 62,7\% women and $32,5 \%$ men (4,8\% did not mentioned its sex). About $31,5 \%$ of studied sample were aged under $30,33,5 \%$ were between 31 and 40 , almost $21 \%$ between 41 and 50 , near $12 \%$ between 51 and 60 , and almost $2 \%$ were aged over 60 years. The major occupational groups included in the sample are teachers $(18,4 \%)$, nurses $(11 \%)$, and bank employees $(9,7 \%)$. About $9,5 \%$ of the sample were people who hold managerial position. The most of studied were employed with the current work place between 3 and 5 years $(20,8 \%)$; on the current position -3 and 5 $(23,6 \%)$ years. Average work experience is almost 14,5 years $(\mathrm{SD}=10,4)$, and work time per week: 41 hours $(\mathrm{SD}=11,52)$. Details contains the Table 1. 


\begin{tabular}{|c|c|c|c|c|}
\hline Variable & & & & \\
\hline Gender & \multicolumn{4}{|c|}{$(\mathrm{n}=3032)$} \\
\hline Male & \multicolumn{2}{|c|}{1034} & \multicolumn{2}{|c|}{32,5} \\
\hline Female & \multicolumn{2}{|c|}{1997} & \multicolumn{2}{|c|}{62,7} \\
\hline Age & \multicolumn{4}{|c|}{$(\mathrm{n}=3169)$} \\
\hline $20-30$ & \multicolumn{2}{|c|}{1005} & \multicolumn{2}{|c|}{31,5} \\
\hline $31-40$ & \multicolumn{2}{|c|}{1066} & \multicolumn{2}{|c|}{33,5} \\
\hline $41-50$ & \multicolumn{2}{|c|}{665} & \multicolumn{2}{|c|}{20,9} \\
\hline $51-60$ & \multicolumn{2}{|c|}{371} & \multicolumn{2}{|c|}{11,6} \\
\hline+60 & \multicolumn{2}{|c|}{62} & \multicolumn{2}{|c|}{1,9} \\
\hline Work experience & \multicolumn{2}{|c|}{$\begin{array}{l}\text { Actual place job } \\
\quad(n=3064)\end{array}$} & \multicolumn{2}{|c|}{$\begin{array}{l}\text { Current position } \\
\quad(n=3052)\end{array}$} \\
\hline $0-6$ months & 204 & 6,4 & 258 & 8,1 \\
\hline 7-11 months & 122 & 3,8 & 171 & 5,4 \\
\hline $1-2$ years & 388 & 12,2 & 533 & 16,7 \\
\hline $3-5$ years & 662 & 20,8 & 752 & 23,6 \\
\hline 6-10 years & 627 & 19,7 & 527 & 16,5 \\
\hline $11-15$ years & 379 & 11,9 & 283 & 8,9 \\
\hline $16-20$ years & 253 & 7,9 & 187 & 5,9 \\
\hline+21 years & 429 & 13,5 & 340 & 10,7 \\
\hline Managerial position & \multicolumn{4}{|c|}{$(n=3186)$} \\
\hline Yes & \multicolumn{2}{|c|}{303} & \multicolumn{2}{|c|}{9,5} \\
\hline No & \multicolumn{2}{|c|}{2883} & \multicolumn{2}{|c|}{90,5} \\
\hline Profession/occupational sector & \multicolumn{4}{|c|}{$(n=3186)$} \\
\hline 1. Accounting/finance & \multicolumn{2}{|c|}{122} & \multicolumn{2}{|c|}{3,8} \\
\hline 2. IT & \multicolumn{2}{|c|}{170} & & \\
\hline 3. Teaching & & & & \\
\hline 4. Nursing & & & & \\
\hline 5. Welfare services/rehabilitation & & & & \\
\hline 6. Police & & & & \\
\hline 7. Office workers in public sector & & & & \\
\hline 8. Bank employees & & & & \\
\hline 9. Blue collar workers & & & & \\
\hline 10. Sales representative & & & & \\
\hline 11. Telesales operators & & & & \\
\hline 12. Physicians & & & & \\
\hline 13. Freight forwarder/shipping & & & & \\
\hline 14. Office workers in private sector & & & & \\
\hline 15. HR employees & & & & \\
\hline 16. Others & & & & \\
\hline
\end{tabular}

Table 1. Demographic and occupational characteristics of the sample 
THE ROLE OF OCCUPATIONAL AND DEMOGRAPHIC

Magdalena Jaworek

Table 2.

One-way ANOVA and Tukey's HSD tests - multiple comparisons for occupational groups in work engagement

\section{Results}

The comparative tests showed that occupational group, job position (managerial vs. non-managerial), age and gender differentiate employees both in total score of work engagement and in most cases its dimensions - vigor, dedication and absorption.

As regards occupational groups, it was found, that the most engaged employees at work represent so diverse professions as sales representative, welfare services/ rehabilitation, and teachers. In turn, the least level of work engagement are reported by telesales operators, blue collar workers, and employing in accounting/ finance. However, each of the three engagement dimensions show a somewhat different patterns. For instance, sales representatives obtained the highest score in dedication and absorption, but relatively low - in vigor (lower than six other studied occupational groups). Details contains the Table 2.

\begin{tabular}{|c|c|c|c|c|c|}
\hline Occupational group & $n=(1175)$ & Vigor & Dedication & Absorption & Engagement \\
\hline 1. Accounting/finance & 100 & $3,04(1,30)$ & $3,40(1,30)$ & $3,15(1,17)$ & $3,20(1,13)$ \\
\hline 2. IT & 100 & $3,45(1,09)$ & $3,95(1,20)$ & $3,64(1,11)$ & $3,67(1,00)$ \\
\hline 3. Teaching & 100 & $3,76(1,24)$ & $4,31(1,13)$ & $3,77(1,34)$ & $3,94(1,11)$ \\
\hline 4. Nursing & 100 & $3,48(1,30)$ & $4,20(1,31)$ & $3,34(1,28)$ & $3,67(1,12)$ \\
\hline $\begin{array}{l}\text { 5. Welfare } \\
\text { services/rehabilitation }\end{array}$ & 100 & $3,84(1,20)$ & $4,35(1,22)$ & $3,75(1,26)$ & $3,98(1,10)$ \\
\hline 6. Police & 101 & $3,31(1,34)$ & $3,99(1,44)$ & $3,42(1,42)$ & $3,58(1,29)$ \\
\hline $\begin{array}{l}\text { 7. Office workers in } \\
\text { public sector }\end{array}$ & 100 & $3,21(1,20)$ & $3,48(1,25)$ & $3,24(1,34)$ & $3,30(1,09)$ \\
\hline 8. Bank employees & 100 & $3,68(1,31)$ & $3,84(1,33)$ & $3,59(1,40)$ & $3,70(1,20)$ \\
\hline 9. Blue collar workers & 89 & $3,21(1,29)$ & $3,13(1,38)$ & $2,75(1,36)$ & $3,04(1,25)$ \\
\hline 10. Sales representative & 100 & $3,10(1,35)$ & $4,32(1,31)$ & $3,88(1,38)$ & $4,06(1,22)$ \\
\hline 11. Telesales operators & 102 & $2,40(1,20)$ & $2,50(1,25)$ & $2,91(1,39)$ & $2,60(1,07)$ \\
\hline 12. Physicians & 83 & $3,20(1,34)$ & $3,90(1,30)$ & $3,34(1,42)$ & $3,48(1,20)$ \\
\hline$F(11,1163)$ & & $11,372 * * *$ & $18,848 * * *$ & $6,712 * * *$ & $13,474 * * *$ \\
\hline Tukey's HSD ${ }^{a}$ & & $\begin{array}{l}\mathbf{5}>1,7,9,11,12 \\
\mathbf{3}>1,11 \\
\mathbf{8}>1,11 \\
\mathbf{4}>11 \\
\mathbf{2}>11 \\
10>\mathbf{6}>11 \\
5,10>\mathbf{7 = 9}>11 \\
5,10>\mathbf{1 2}>11 \\
\mathbf{1 0}<1,6,7,9,11,12 \\
3,5,8,10>\mathbf{1}>11 \\
\mathbf{1 1}<1,2,3,4,5,6, \\
\quad 7,8,9,10,12\end{array}$ & $\begin{array}{l}\mathbf{5}>1,7,9,11 \\
\mathbf{1 0}>1,7,9,11 \\
\mathbf{3}>1,7,9,11 \\
\mathbf{4}>1,7,9,11 \\
\mathbf{6}>9,11 \\
\mathbf{2}>9,11 \\
\mathbf{1 2}>9,11 \\
\mathbf{8}>9,11 \\
3,4,10>\mathbf{7}>11 \\
3,4,5,10>\mathbf{1}>11 \\
2,3,4,5,6,8,10,12>\mathbf{9} \\
\mathbf{1 1}<1,2,3,4,5,6, \\
\quad 7,8,9,10,12\end{array}$ & $\begin{array}{l}\mathbf{1 0}>1,7,9,11 \\
\mathbf{3}>1,9,11 \\
\mathbf{5}>9,11 \\
\mathbf{2}>9,11 \\
\mathbf{8}>9,11 \\
\mathbf{6}>9 \\
\mathbf{4}=\mathbf{1 2} \\
10>\mathbf{7} \\
3,10>\mathbf{1} \\
\mathbf{1 1}<2,3,5,8,10 \\
\mathbf{9}<2,3,5,6,8,10\end{array}$ & $\begin{array}{l}\mathbf{1 0}>1,7,9,11,12 \\
\mathbf{5}>1,7,9,11 \\
\mathbf{3}>1,7,9,11 \\
\mathbf{8}>9,11 \\
\mathbf{4}=\mathbf{2}>9,11 \\
\mathbf{6}>11 \\
10>\mathbf{1 2}>11 \\
3,5,10>\mathbf{7}>11 \\
3,5,10>\mathbf{1}<11 \\
\mathbf{9}<2,3,4,5,8,10 \\
\mathbf{1 1}<1,2,3,4,5,6, \\
\quad 7,8,10,12\end{array}$ \\
\hline
\end{tabular}

$* * * p<, 001 ;{ }^{a}$ all displayed inequalities are statistical significant at $p<, 05$ 
In case of job position, obtained results are in accordance with predictions. People who holds managerial positions reported higher overall work engagement, as well in regards to all three dimensions (see: Table 3).

THE ROLE OF OCCUPATIONAL AND DEMOGRAPHIC

Magdalena Jaworek

\begin{tabular}{llllll}
\hline Job position & $\mathbf{n}=\mathbf{6 0 4}$ & Vigor & Dedication & Absorption & Engagement \\
\hline Managerial & 304 & $3,98(1,16)$ & $4,37(1,18)$ & $4,08(1,19)$ & $4,14(1,02)$ \\
\hline Non-managerial & 300 & $3,52(1,20)$ & $3,96(1,28)$ & $3,62(1,24)$ & $3,70(1,11)$ \\
\hline$t(602)$ & & $-4,81^{* * *}$ & $-4,10^{* * *}$ & $-4,71^{* * *}$ & $-5,16^{* * *}$ \\
\hline Gender & $\mathrm{n}=2033$ & & & \\
\hline Male & 1034 & $3,54(1,21)$ & $3,91(1,27)$ & $3,52(1,29)$ & $3,66(1,14)$ \\
\hline Female & 999 & $3,62(1,24)$ & $4,06(1,28)$ & $3,65(1,27)$ & $3,77(1,13)$ \\
\hline$t(2031)$ & & $-1,48$ & $-2,54 *$ & $-2,29 *$ & $-2,34 *$ \\
\hline
\end{tabular}

$* p<, 05 ; * * * p<, 001$

Table 3.

Independent group $t$-tests in work

Significant differences concerning the work engagement were observed also in terms of age. Surprisingly, older employees are more vigorous, dedicated, and absorbed in their work, than they younger fellows. However, it must be stressed that significant differences in total score of work engagement, dedication and absorption were observed in regard to employees between 20-30 and above 41 years old, and 31-40 and above 50 years old. The level of vigor was significant higher only among people 50+ in comparison to rest age groups. Details contains the Table 4.

\begin{tabular}{lllllll}
\hline Age & & $\mathbf{n}=\mathbf{1 7 2 5}$ & Vigor & Dedication & Absorption & Engagement \\
\hline 1. & $20-30$ & 430 & $3,46(1,27)$ & $3,80(1,31)$ & $3,54(1,26)$ & $3,54(1,15)$ \\
\hline 2. & $31-40$ & 430 & $3,54(1,22)$ & $3,94(1,28)$ & $3,60(1,28)$ & $3,70(1,13)$ \\
\hline 3. & $41-50$ & 430 & $3,58(1,28)$ & $4,05(1,36)$ & $3,69(1,30)$ & $3,77(1,16)$ \\
\hline 4. & +50 & 433 & $3,81(1,23)$ & $4,25(1,27)$ & $3,76(1,37)$ & $3,94(1,16)$ \\
\hline$F(3,1718)$ & & $6,227 * * *$ & $9,331 * * *$ & $8,042 * * *$ & $9,094 * * *$ \\
\hline \multicolumn{2}{l}{ Tukey's HSD } & & $1,2,3<4^{*}$ & $1<3 *, 4^{*}$ & $1<3^{*}, 4^{*}$ & $1<3^{*}, 4^{*}$ \\
& & & $2<4^{*}$ & $2<4 *$ & $2<4 *$ \\
\hline
\end{tabular}

$* p<, 05 ; * * * p<, 001$

Gender, as other factors taken into consideration in current study, appeared to be significant in relation to work engagement also. It was observed, that women are slightly more engaged at work, than men, as regards total-scores on the UWES, as well dedication and absorption. No gender differences were observed in vigor. These results are partially contrary to findings by Schaufeli and Bakker (2003), Table 4. One-way ANOVA and Tukey's HSD tests - multiple comparisons for age groups in work engagement who found that men are more dedicated and absorbed in their work than females. Details contains the Table 4. 
THE ROLE OF OCCUPATIONAL AND DEMOGRAPHIC

Magdalena Jaworek

\section{Discussion}

The aim of the study was examine the role of occupational and demographic factors in relation to work engagement. The findings confirmed that occupational group, job position, age and gender are associated with work engagement, and all formulated hypotheses (1, 2, 3 and 4) were supported. However differences in mean levels of engagement within studied factors are, although significant, relatively small and they have not exceed the size of one standard deviation. Nevertheless, findings indicate that work engagement is complicated phenomenon and requires to be explored in terms of not only organizational or psychological factors, but individual determinants also.

In current study, the most engaged employees turned to be sales representatives, welfare services/rehabilitation, and teachers, and the least engaged at work - sales operators and blue collar workers. Similarly to findings of current study, teachers among other occupational groups reported high work engagement in examination by Smulders (2006, cited in: Bakker, 2009) and Schaufeli et al. (2006). However, Innstrand (2016) found, that teachers in comparison to seven other studied occupational groups were the least vigorous. The least engaged employees in comparison to other studied occupational groups turned to be telesales operators and blue collar workers. These outcomes are in line of others investigations to some extent. Relatively low result in work engagement was obtained by blue collar workers comparing to managers, educators, and police officers in study by Schaufeli et al. (2006). These occupations seems to be associated with few resources (low wages, low social recognition, weak prospects of opportunities for development, etc.) and high job demands (low task variety).

Each occupation (and job position) provides the individual different resources in the form of prestige, proper wages, sense of safety or/and meaning, abilities of personal development, etc. Also, practicing the occupation are associated with certain job resources and job demands regardless of the work place. It seems, that some occupations provide individuals more resources than others, and that is why they are more desired. In line of JD-R model and COR, more resources leads directly to well-being, what can be translates into the rule: The more you get (in sense of resources) from what you do, the better you feel, the more you satisfied with your job, and finally - are engaged with your work. Similarly, the results concerning higher work engagement among mangers can be clarified. Managerial position is usually associated with higher job control and autonomy in compared to people who are not managers. And, job control belonging to job resources, is related to job satisfaction (i.e. Finn, 2001).

However, resources can be regarded also from individual point of view. There are occupations which are attractive for some people because of other reasons, than high wages and/or prestige. They decide to work in professions which are underpaid and not necessary prestigious, but are related e.g. to certain mission, 
as helping others. In current study, two occupational groups who turned to be the most engaged in comparison to others, belong to so called social services jobs. Usually, people who decide to work in social services are mainly motivated by desire to help others, which is the need of higher order than for example social prestige. Maybe, sense of mission activates positive affective-cognitive states, like internal motivation and enthusiasm, which are associated with work engagement. However, this explanation should be verified in further investigations. Especially, that two occupational groups in that study, which are belong to social services also, i.e. nurses and physicians reported medium or lower level of work engagement in comparison to rest occupations.

On the other hand, organizations attract people with certain dispositions (see: Schneider, 1987), what may relate to occupational groups also. In current study, the highest level of work engagement reported sales representatives. This occupation is associated with direct interpersonal contact, assertiveness, and activity, what is related to the extraversion (see: Zawadzki et al., 1998). Extraverts, as value interpersonal contact, seek the job, which is associated with it. In turn, HR managers choosing the best candidates on position of sales representatives who have interpersonal and persuasive skills, what is the basis of that occupation. Thus, most of sales representatives are extraverts what correlates with work engagement (Zaidi et al., 2013). In the same vein, findings concerning higher work engagement among managers can be explained.

Results of the present study regarding higher engagement among older employees comparing to youngers are confirmed by other investigations (Schaufeli and Bakker, 2003; Schaufeli et al., 2006; Haley et al., 2013; Pocnett et al., 2015). Schaufeli and Bakker (2003) found that older employees reported higher engagement in the work than youngers, however the amount of shared variance was rather small (below 2\%). Haley et al. (2013) found that older employees were more dedicated than their younger counterparts. In turn, studies by Pocnett et al. (2015) revealed positive relationship work engagement with age, but only among Swiss workers (not foreign ones). The findings can be explained by the COR theory to some extent. As people grow older, the more emotionally mature they are, the more personal competencies they have and generally they are more experienced, both in the work as in life. These personal resources may be translated into job satisfaction, performance and just engagement. In Kim's and Kang's studies (2017) it was found that well-regulated emotion and strong commitment to career mediate the relationship between age and work engagement. Age is also strictly associated with generational cohort, which displays certain characteristics and contributes in their own way to the workplace (Hoole and Bonnema, 2015). Hoole and Bonnema (2015) observed that representatives of Baby Boomer generation, as the oldest one, obtained higher level of work engagement and work meaningfulness in comparison to younger fellows - representatives of $\mathrm{X}$ and $\mathrm{Y}$ 
THE ROLE OF OCCUPATIONAL AND DEMOGRAPHIC

Magdalena Jaworek generations. This result can be explained by natural changes in human life also. People above 50 years (the most engaged in that study) seem to be less burdened with parental responsibility because their children usually do not require care and attention as children of younger fellows. Therefore, older employees may concentrate on his job and engaged with it to more extent. Broader explanation of higher work engagement among older employees includes the work by James et al. (2011).

In turn, slightly higher total score in work engagement, as well in dedication and absorption among women in comparison to men, seems to be interesting in the face of findings of other studies. Higher work engagement was reported by men in studies by Schaufeli and Bakker (2003) and Steyn and Grobler (2016). In cross - National study by Schaufeli et al. (2006), in which used data from ten countries, it was found that in only three of them, women had higher scores in work engagement (or in some of dimensions) compared to men. Maybe, results concerning gender differences should be considered in social and/or culture context rather, than in regard of psychological theories (see also: Jaworek and Dyląg, 2015).

Results of current study are rather descriptive in character, so they should be treated as a starting point to further, correlational investigations. As studied construct is associated with many positive outcomes, both for individual and organization, it is important to investigate which factors influence high and low work engagement. Do they belong to personal traits or organizational environment? Or maybe they are related to specific professional job tasks that exceed average abilities of individual. It is especially important if employers must tackle with situations of low job performance, high job turnover and absenteeism, what is associated among others with low work engagement (Ali and Baloch, 2009; Schaufeli and Bakker, 2004). So, it is worth to answer the question: what is wrong with that profession, which representatives have less vigor, are less absorbed and dedicated to their job (e.g. telesales operators or blue collar workers), and what can we do to improve it? And what is special in some professions of high engagement (e.g. sales representatives), what can be applied to other occupational groups. Results of that study are useful for managers also. They should pay more attention to younger employees providing them more support, and value elder ones, who are more committed to their job, than youngers, and probably more loyal to the organization.

Current research enrich the knowledge about the work engagement, especially among Polish employees. However, this study has several limitations. First of all, although sample includes diverse occupational groups, it does not fully reflects the occupational structure of population in Poland. Moreover, it did not taken into account all occupations, what would be difficult enough, but comparative analyses 
of that factor should be treated with caution. The analyses of interactions between analyzed occupational or demographic factors in relation to work engagement would show its specificity in more details.

\section{References}

Ali, N., Baloch, Q.B. (2009), „Predictors of organizational commitment and turnouver intentions of medical representatives (an empirical evidence of Pakistani companies)", Journal of Managerial Sciences, Vol. 3 No. 2, pp. 263-273.

Babcock-Roberson, M., Strickland, O.J. (2010), "The relationship between charismatic leadership, work engagement, and organizational citizenship behaviors", The Journal of Psychology, Vol. 144 No. 3, pp. 313-326.

Bakker, A.B. (2009), "Building engagement in the workplace", in: Burke R.J., Cooper C.L. (Eds.), The peak performing organization, Oxon, UK: Routledge, pp. 50-72.

Bakker, A.B., Bal, P.M. (2010), "Weekly work engagement and performance: a study among starting teachers", Journal of Occupational and Organizational Psychology, Vol. 83, pp. 189-206. DOI: 10.1348/096317909X402596

Bakker, A.B., Schaufeli, W.B., Leiter, M.P., Taris, T.W. (2008), "Work engagement: An emerging concept in occupational health psychology", Work \& Stress, Vol. 22 No. 3, pp. 187-200. DOI: 10.1080/02678370802393649

Bezuidenhout, A., Cilliers, F.V.N. (2010), "Burnout, work engagement and sense of coherence in female academics in higher-education institutions in South Africa", South Africa Journal of Industrial Psychology, Vol. 36 No. 1, pp. 1-10. DOI: 10.4102/sajip. v36i1.872

Demerouti, E., Bakker, A.B., de Jonge, J., Janssen, P.P., Schaufeli, W.B. (2001), Burnout and engagement at work as a function of demands and control, Scandinavian Journal of Work, Environment and Health, Vol. 21 No. 4, pp. 279-286. DOI: 10.5271/ sjweh.615

Haley, L.-M., Mostert, K., Els, C. (2013), "Burnout and Work Engagement for Different Age Groups: Examining Group-Level Differences and Predictors", Journal of Psychology in Africa, Vol. 23 No. 2, pp. 283-296.

Hallberg, U.E., Johansson, G., Schaufeli, W.B. (2007), "Type A behavior and work situation: Associations with burnout and work engagement", Scandinavian Journal of Psychology, Vol. 48 No. 2, pp. 135-142. DOI: 10.1111/j.1467-9450.2007.00584.x

Hobfoll, S.E. (1989), "Conservation of Resources. A new Attempt at Conceptualizing Stress", American Psychologist, Vol., 44 No. 3, pp. 513-524.

Hobfoll, S.E. (2006), Stres, kultura i społeczność. Psychologia i filozofia stresu, Gdańskie Wydawnictwo Psychologiczne, Gdańsk.

Hoole, C., Bonnema, J. (2015), "Work engagement and meaningful work across generational cohorts", South Africa Journal of Human Resource Management, Vol. 13 No. 1. DOI: 10.4102/sajhrm.v13i1.681

Innstrand, S.T. (2016), “Occupational differences in work engagement: A longitudinal study among eight occupational groups in Norway", Scandinavian Journal of Psychology, Vol. 57 No. 4, pp. 338-349. DOI: 10.1111/sjop.12298

James, B.J., McKechnie, S., Swanberg, J. (2011), "Predicting employee engagement 
THE ROLE OF OCCUPATIONAL AND DEMOGRAPHIC

Magdalena Jaworek in an age-diverse retail workforce", Journal of Organizational Behavior, Vol. 32, pp. 173-196. DOI: 10.1002/job.681

Jaworek, M., Dyląg, A. (2015), "Perception of work environment among women and men: workload and autonomy in relation to job engagement", Jagiellonian Journal of Management, Vol. 1 No. 2, pp. 155-174. DOI: 10.4467/2450114XJJM.15.012.4469

Jaworek, M., Dyląg, A. (2016), "Workaholism and work engagement: differences and mutual relationship", Jagiellonian Journal of Management, Vol. 2 No. 4, pp. 275-286. DOI: 10.4467/2450114XJJM.16.022.6091

Kahn, W.A. (1990), "Psychological conditions of personal engagement and disengagement at work", Academy of Management Journal, Vol. 33 No. 4, pp. 692-724.

Narainsamy, K., van der Westhuizen, S. (2013), "Work Related Well- Being: Burnout, Work Engagement, Occupational Stress and Job Satisfaction Within a Medical Laboratory Setting", Journal of Psychology in Africa, Vol. 23 No. 3, pp. 467-474. DOI: 10.1080/14330237.2013.10820653

Pocnet, C., Antonietti, J.-Ph., Massoudi, K., Györkös, Ch., Becker, J., de Bruin, G.P., Rossier, J. (2015), "Influence of Individual Characteristics on Work Engagement and Job Stress in a Sample of National and Foreign Workers in Switzerland", Swiss journal of Psychology, Vol. 74 No. 1, pp. 17-27. DOI: 10.1024/1421-0185/a000146

Rothmann, S. (2008), "Job satisfaction, occupational stress, burnout and work engagement as components of work-related wellbeing", South Africa Journal of Industrial Psychology, Vol. 34 No. 3, pp. 11-16.

Schaufeli, W.B., Bakker, A. (2004), „Job demands, job resources, and their relationship with burnout and engagement: a multi-sample study", Journal of Organizational Behavior, Vol. 25, pp. 293-315. DOI: 10.1002/job.248

Schaufeli, W.B., Bakker, A.B. (2003), Test manual for the Utrecht Work Engagement Scale, unpublished manuscript, available at: http://www.schaufeli.com.

Schaufeli, W.B., Bakker, A.B., Salanova, M. (2006), "The measurement of work engagement with a short questionnaire: a cross national study", Educational and Psychological Measurement, Vol. 66, pp. 701-716. DOI: 10.1177/0013164405282471

Schaufeli, W.B., Salanova, M., Gonzales-Roma, V., Bakker, A. (2002), “The measurement of engagement and burnout: a two sample confirmatory factor analytic approach", Journal of Happiness Studies, Vol. 3, pp. 71-92.

Schaufeli, W.B., Taris, T.W., van Rhenen, W. (2008), "Workaholism, Burnout, and Work Engagement: Three of a Kind or Three different Kinds of Employee Well-being?", Applied Psychology: An International Review, Vol. 57 No. 2, pp. 173-203. DOI: 10.1111/j.1464-0597.2007.00285.x

Schneider, B. (1987), "The people make the place”, Personnel Psychology, Vol. 40, pp. 437-453.

Shimazu, A., Schaufeli, W.B., Kamiyama, K., Kawakami, N. (2015), „Workaholism vs. Work engagement: the two different predictors of future well-being and performance", International Journal of Behavioral Medicine, Vol. 22, pp. 18-23. DOI: 10.1007/ s12529-014-9410-x

Steyn, R., Grobler, S. (2016), "Sex differences and work engagement: a study cross 27 South African Companies", Journal of Contemporary Management, Vol. 13 No. 1, pp. 461- 481 . 
Xanthopoulou, D., Bakker, A.B., Demerouti, E., Schaufeli, W.B. (2007), "The Role of Personal Resources in the Job Demands-Resources Model", International Journal of Stress Management, Vol. 14 No. 2, pp. 121-141. DOI: 10.1037//1072 $-5245.14 .2 .121$

THE ROLE OF OCCUPATIONAL AND DEMOGRAPHIC

Magdalena Jaworek

Zaidi, N.R., Wajid, R.A., Zaidi, F.B., Zaidi, G.B., Zaidi, M.T. (2013), "The big five personality traits and their relationship with work engagement among public sector university teachers at Lahore", African Journal of Business Management, Vol. 7 No. 15, pp. 1344-1353. DOI: 10.5897/AJBM12.290

Zawadzki, B., Strelau, J., Szczepaniak, P., Śliwińska, M. (1998), Inwentarz osobowości NEO-FFI Costy i McCrae. Adaptacja polska. Podręcznik, Pracownia Testów Psychologicznych: Warszawa. 